\title{
Evaluation Of Subcutaneous Tissue Response To Implanted Samples Of Acrylic Resin Mixed With Metal Fillers
}

\author{
El Sayed Galal Khedr* And Ahmed H. Yossef**
}

\author{
Department Of Histology*; Faculty Of Medicine And Department Of \\ Prothodontic**;Faculty Of Dental Medicine;Al Azhar University
}

\begin{abstract}
This study was conducted to to study the subcutaneous tissue response as well as some properties of of heat acrylic resin mixed with Aluminum (Al) and Silver (Ag). $(2 \% ; 3 \% ; 5 \% ; 10 \%)$ concentrations of $\mathrm{Al}$ and $\mathrm{Ag}$ were added separately to heat cured acrylic resin and the mechanical properties of themixture were examined by the common Elson technique. The addition of $2 \%$ of either $\mathrm{Al}$ and $\mathrm{Ag}$ to heat acrylic resin increased its transverse strength as well as its impact strength; while 5\% and $10 \%$ cocentrations reduced both the transverse and the impact strengths of the resin . Therefore $2 \%$ concentrationwas chosen for subcutaneous tissue implantation. Three pellets of acrylic resin one containing $\mathrm{Al}$;one containing $\mathrm{Ag}$ and the third was free from both elements as a control were each implanted in the subcutaneous c.t. of twenty male albino rats. A thick connective tissue capsule surrounding each pellet was formed . Al containing acrylic resin was surrounded with a thicker capsule formed of collagen fibers infiltrated with many inflammatory cells ; while the connective tissue reaction against the pure acrylic resin and $\mathrm{Ag}$ acrylic resin was minimal in the form of thin capsule formed of collagen fibers; fibroblasts and few inflammatory cells . Measurements of the capsule thickness and the number of inflammmayory cells infiltrating the capsule showed a significant increase in $\mathrm{Al}$ group than in $\mathrm{Ag}$ and control groups .In conclusion the addition of $2 \%$ of either $\mathrm{Al}$ and $\mathrm{Ag}$ to heat acrylic resin improved its strength but $\mathrm{Ag}$ containing heat acrylic resin was more tolerable to tissue.
\end{abstract}

\section{Introduction}

Acrylic resins are the most widely used materials for denture base processing and also used in many surgical procedures because the ease of manipulation; repair; pigmintation and insolubility in oral fluids (Omar and Shehata; 1993). Attempts have been made to improve the physical properties of acrylic resins and to overcome their drawbaks by adding different substa nces (Dixon et al ;1991). Adding metal fillers to dental base resin decreased the coefficient of thermal expansion (Sehajpal and Sood ;1989). Also it increased the impact and compressive strengths and decreased the wrap- ability of the resin (Ragab; 1992). Biological compatibility of tissues to acrylic resins is quite essential because these materials have many uses including embedding within the tissue (A.D.A. 1982 ) . Many investigators have used acrylic resins and found them harmless to living tissue (Hodosh et al., 1970). However others reported that biological changes of some resins was harmful and might induced tumours in laboratory animals (Habal and Powell; 1980). In this study we tried to examine the histological picture of the subcuta neous tissue response to Aluminum and silver containing acrylic resin in 
concentrations that improve the physical properties of the resin .

\section{Material And Methods}

Two metal fillers were used in this study; Silver and Aluminum in the form of pure metal powder. They were added to heat cured powder at 2\%,3\%, $5 \%$ and $10 \%$ concentrations. 20 speci mens were prepared for each concent ration of silver and Aluminum . Another 20 specimens from the metal free acrylic resin were prepared as a control group. Specimens were prepared accor ding to the American Dental Associ ation (ADA) specification No. 15 and 12 for denture base polymers and subjected to travsverse strenght and impact strength tests by the standered Elson technique. Pellets of $2 \times 4 \mathrm{~mm}$ diameter representing the three different group specimens were prepared. Histological study was carried on thirty male albino rats. Three midline abdo minal skin incisions were made in each rat under general anaesthesia. The different pellets were implanted subcutaueorsly and the skin was closed using surgical thread .Five rats were anaesthetised weekly and the connective tissue surrounding different implanted pellets were dissected for four weeks and subjected for histological examination using the paraffine technique and suitable staining methods incluing $\mathrm{Hx} \& \mathrm{E}$, toluidie blue and trichrome stains . Results were tabulated and analysed using the image analyzer and suitable statistical analysis tests for the results .

\section{Results \\ Physical results}

The addition of $2 \%$ and $3 \%$ of Silver and Aluminum fillers to the heat acrylic resin increased the transvers strength as well as the impact strength . These increase in mechanical properties was found to be statistically significant . With higher concentrations of both metals both the transverse strength and the impact strength were reduced table ( $1 \& 2)$.

\section{Histological results}

Tissue sections of the connective tissue capsule surrounding the implanted pellets of metal free heat cured acrylic resin after two weeks showed that the formed capsule was very thin and formed of inflammatory cells mainly fibroblasts and collagen fibers fig .(1-A;B\&C). Measurements of the capsule thickness showed that the mean diameter was $(40.374 \pm 3.7)$ um fig (6) . In the first week the inflammatory cells were crowded and surrounded by congested blood vessels fig.(1-C) . The number of cells was gradually reduced. The mean number of cells in the capsule surrounding metal free control samples after four weeks was ( $200 \pm 0.24$ )cell / fixed area fig .(5) .

Tissue sections of connective tissue capsule surrounding implanted pellets of heat cured acrylic resin containing $2 \%, 3 \%$ Silver metal filler after two weeks showed that the formed capsul was thin fig. (2-A). The capsule was formed mainly of fibroblasts and other infiltrating inflammatory cells including mast cells; macrophages and lymphocytes fig. (4-A\&C). The number of cells was gradually decreasing. Measurements of the capsule thickness after four weeks showed that the mean diameter was (122.082 \pm 16.6$)$ um fig (6) The mean cell number in the capsule surrounding Silver containing samples was (515 \pm 0.46$)$ cell /fixed area fig .(5) .

Tissue sections of the connective tissue capsule surrounding implanted pellets of heat acrylic resin containg $2 \%, 3 \%$ Aluminum metal filler after two weeks showed that the formed capsule was the thickest and surrounded by many congested blood vessels . The 
capsule was formed of dense inflammatory cells including fibroblasts mast cells , macrophages and lymphocytes . The number of cells was gradually decreasing but a large number persisted up to the fourth week . The mean cell number was $(650 \pm 0.69)$ cell /fixed area fig.(5) and the mean diameter of the capsule was

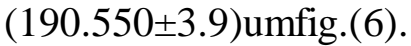

Fig.(1-A ): Section in the connective tissue capsul surrounding metal free Acrylic resin showing thin capsule Infiltrated with inflammatory cells .

(Hx \&E $\quad$ x200)

Fig. (1-B) : High magnification of fig.(1) showing fibroblasts and collagen bundles . $\left(\begin{array}{lll}H x & \& & \mathrm{E}\end{array} 400\right)$

Fig. (1-C) : Section in the connective tissue Capsule surrounding metal free acryli c resin showing inflammatory cells ; collagen bundles and congested blood vessels. (Masson trichrome x 200)
The mean diameters of connective tissue capsules in Aluminum and Silver groups were higher than that in the control group. However the formed capsule in Aluminum group was thicker than that in Silver group table(4) fig.(6) . Also the mean numbers of cells in the formed capsules in Aluminum and Silver groups were higher than that in the control group but in Aluminum group it was higher than in Silver group table(3) fig .(5).

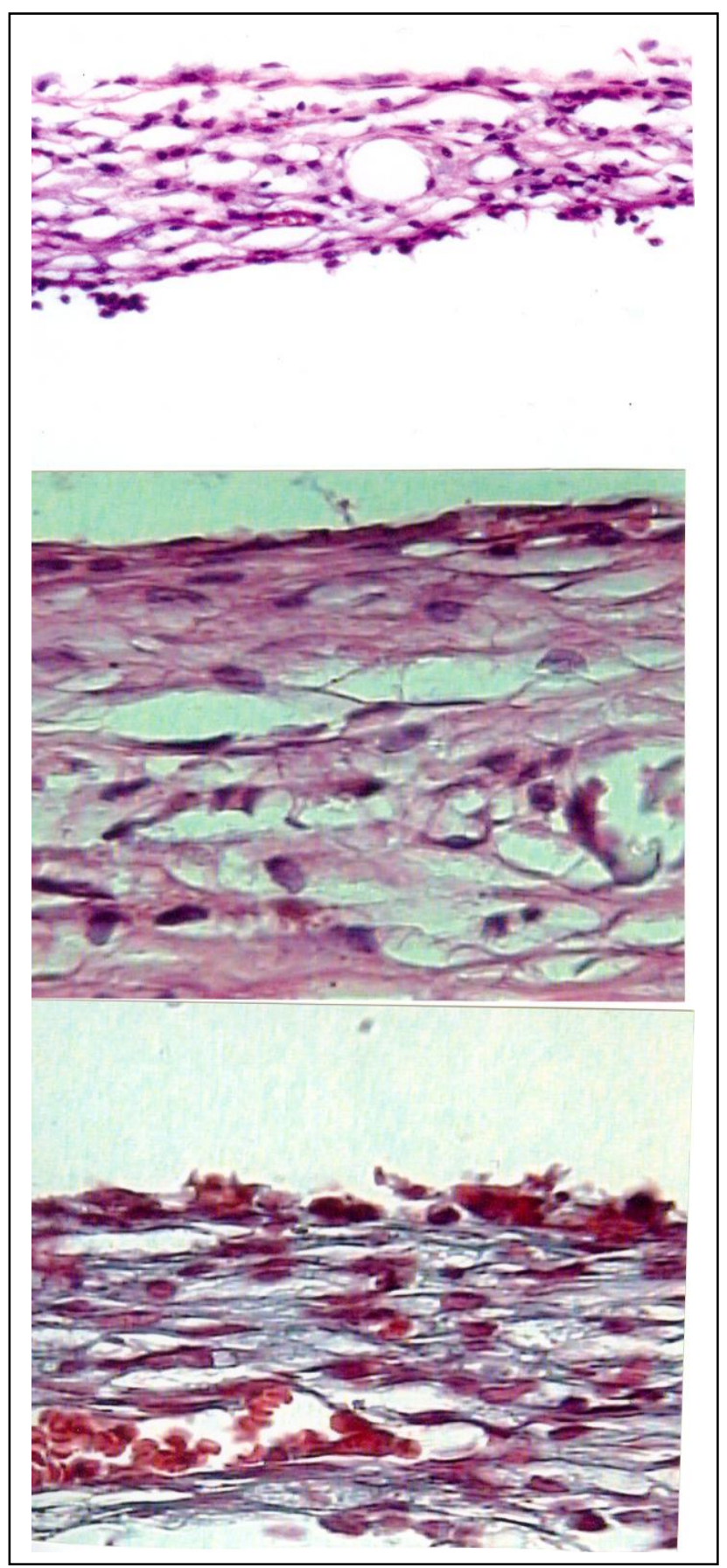


Fig. (2- A) :Section in the connective tissue capsule surrounding Aluminum containing acrylic resin showing thick capsule infiltrated with many inflammatory cells. ( Hx \&E $\quad$ x 200 )

Fig . (2-B) : High magnification of fig. (2-B) showing crowded fibroblasts and dense bundles . ( $\mathrm{Hx} \& \mathrm{E} \quad \mathrm{x} 400)$

Fig. (2-C) : Section in the connective tissue capsule surrounding Aluminum containg acrylic resin showing crowded inflammatory cells and collagen bundles . (Masson trichrome $\quad$ x 200)

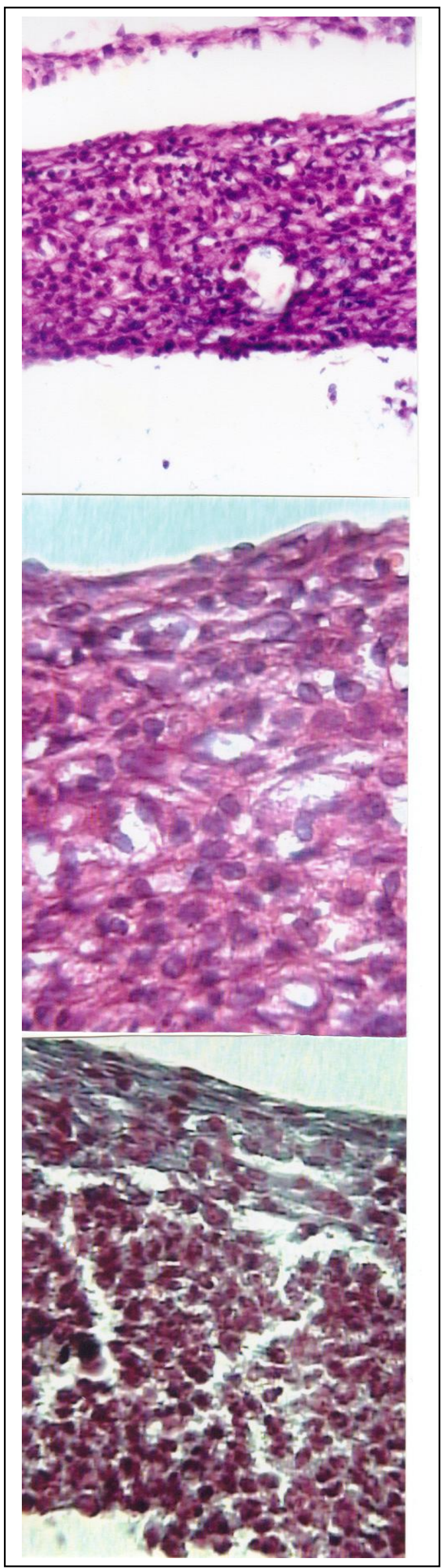


Fig .(3-A) :Section in the connective tissue capsule surrounding Silver containg acrylic resin showing thin capsule infiltrated with inflammatory cells . ( Hx \&E x 200)

Fig . (3-B): High magnification of fig. (3-A) showing collagen bundles and fibroblasts ( Hx \&E $\quad x$ 400)

Fig. (3-C) : Section in the connective tissue capsule surrounding Silver containing

inflammatory cells and collagen bundles (Masson trichrome x 200)

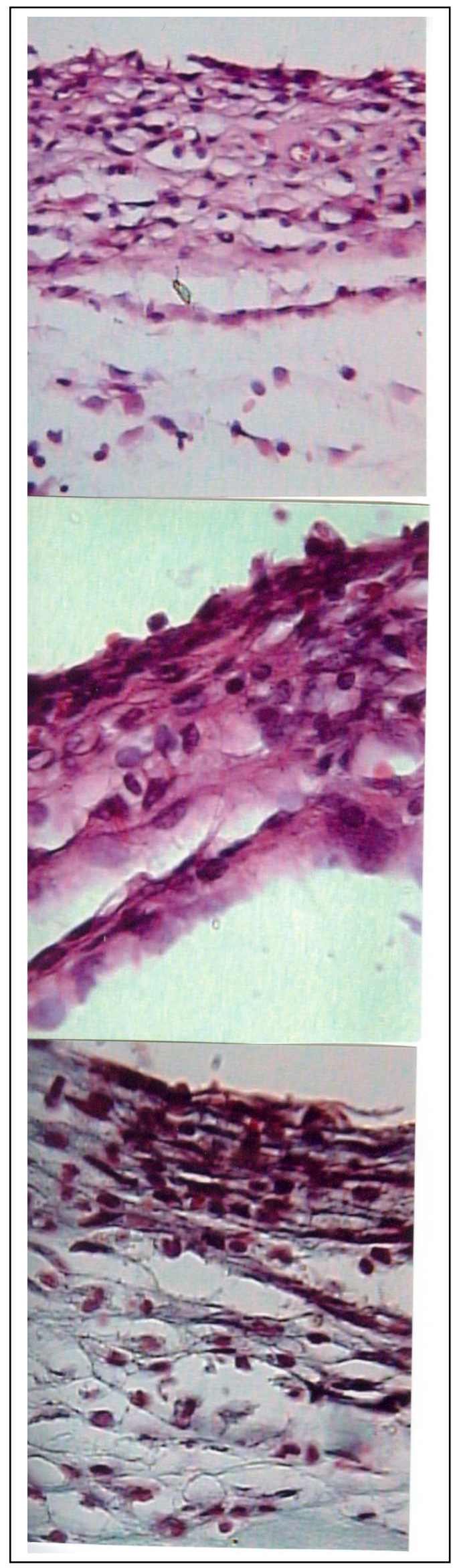


Fig.(4-A): Inflammatory cells in the capsule including numerous fibroblasts $(\mathrm{F})$; a histeocyte $(\mathrm{H})$; a neotrophil(N) ;a plasma cell(p) and a lymphocyte(L) $\mathrm{Hx} \& \mathrm{E} \quad \mathrm{X} 400)$

Fig. (4-B) : The formed capsule showing thick collagen bundles and few fibroblasts.

(Hx\&E $\quad \mathrm{x} 1500)$

Fig, (4-C) : The connective tissue capsule showing mast cells ; fibroblasts and lymphocytes

(Toluidine blue $\mathrm{x} 1000)$

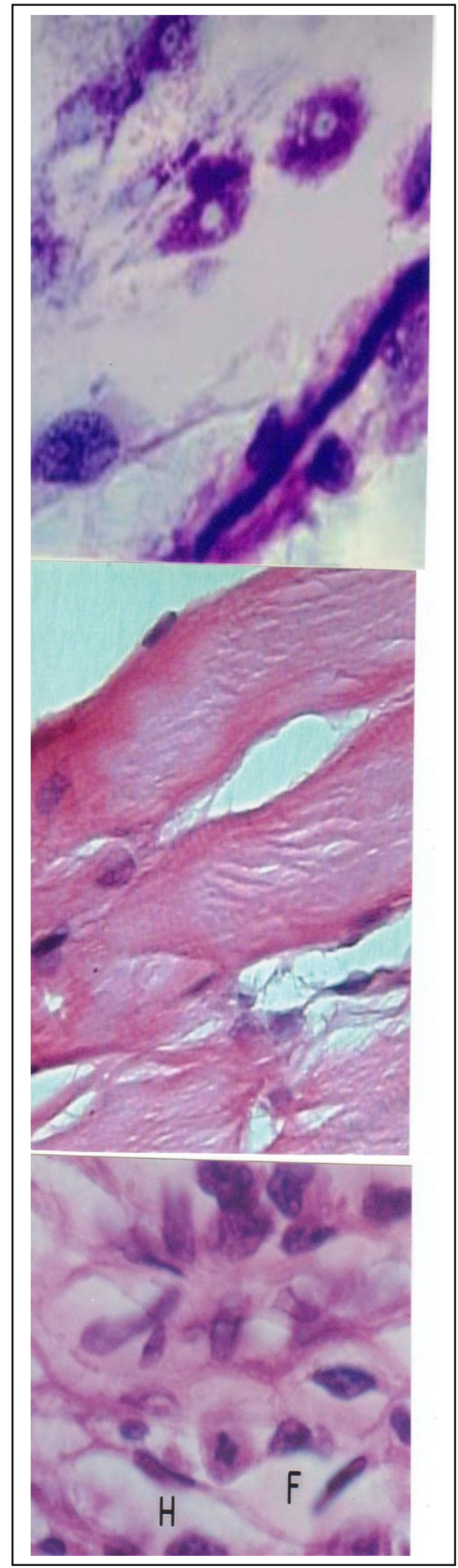


Table(1): Transverse strength of Silver and Aluminum filled heat cured acrylic $\operatorname{resin}\left(\mathrm{Kg} / \mathrm{mm}^{2}\right)$

\begin{tabular}{|l|l|l|l|l|l|l|}
\hline MATERIALS & \multicolumn{2}{l|}{ SILVER } & \multicolumn{2}{l|}{ ALUMINUM } & F. VALUE \\
\hline & MEAN & S.D & MEAN & S.D & & \\
\hline $0 \%$ & 8.85 & 0.71 & 8.84 & 0.71 & & \\
\hline $2 \%$ & 8.90 & $0.11 *$ & 9.02 & $0.43 *$ & 250.14 & $*$ \\
\hline $3 \%$ & 8.70 & $0.12 *$ & 8.50 & $0.44 *$ & 402.82 & $*$ \\
\hline $5 \%$ & 7.04 & 0.76 & 7.30 & 0.36 & & \\
\hline $10 \%$ & 5.01 & 0.86 & 5.17 & 0.30 & & \\
\hline
\end{tabular}

$*=$ Significant at $5 \%$

Table(2):Transverse strength of Silver and Aluminum filled heat cured crylic $\operatorname{resin}\left(\mathrm{Kg} / \mathrm{mm}^{2}\right)$

\begin{tabular}{|c|c|c|c|c|c|}
\hline \multirow[t]{2}{*}{ MATERIALS } & \multicolumn{2}{|c|}{ SILVER } & \multicolumn{2}{|c|}{ ALUMINUM } & F. VALUE \\
\hline & MEAN & S.D & MEAN & S.D & \\
\hline $0 \%$ & 0.48 & 0.05 & 0.49 & 0.04 & \\
\hline $2 \%$ & 0.60 & $0.03 *$ & 0.62 & $0.01 *$ & $46.02 *$ \\
\hline $3 \%$ & 0.56 & $0.03 *$ & 0.50 & $0.02 *$ & $52.0 *$ \\
\hline $5 \%$ & 0.45 & 0.04 & 0.45 & 0.05 & \\
\hline $10 \%$ & 0.30 & 0.06 & 0.34 & 0.06 & \\
\hline
\end{tabular}

$*$ = Significant at $5 \%$

\section{NUMBER OF CELLS IN CAPS ULES \\ S URROUNDING DIFFERENT ACRYLIC \\ RES INS}

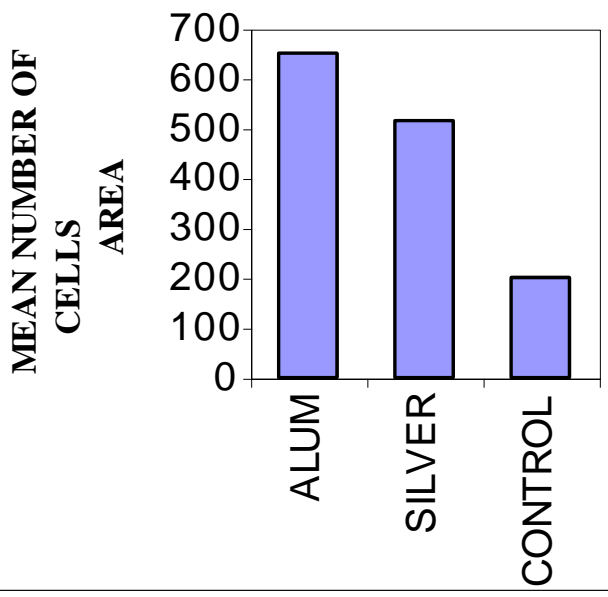

Fig. (5 ) : Number of cells in the C. T. capsules surrounding different acrylic resins 


\begin{tabular}{|c|c|c|c|}
\hline & ALUM & SILVER & CONTROL \\
\hline Sum & 13000 & 10300 & 4000 \\
\hline Mean & 650 & 515 & 200 \\
\hline Std. Deviation & 0.69 & 0.46 & 0.24 \\
\hline T value & 1.240 & 1.224 & \\
\hline P value & $<0.05$ & $<0.05$ & $* *$ \\
\hline
\end{tabular}

Table ( 3 ) : showing quantitative results of the mean number of cells in C.T. capsules of different groups .

** Significan change between metal filler and control groups at $\mathrm{P}<0.05$

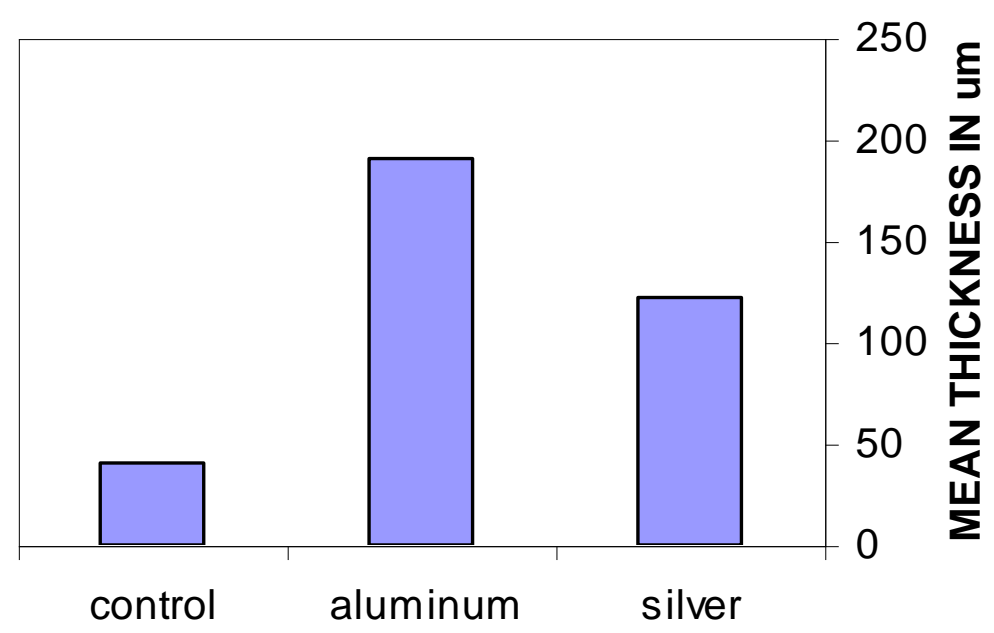

Fig .(6) :Histogram showing the mean thickness of the C . T . capsules surrounding different acrylic resins .

\begin{tabular}{|l|l|l|l|}
\hline & control & aluminum & silver \\
\hline Sum & 605.61 & 2858.26 & 1831.23 \\
\hline Mean & 40.374 & 190.5507 & 122.082 \\
\hline $\begin{array}{l}\text { Std. Error } \\
\text { of Mean }\end{array}$ & 0.967495 & 1.016168 & 4.280251 \\
\hline $\begin{array}{l}\text { Std. } \\
\text { Deviation }\end{array}$ & 3.747094 & 3.9356 & 16.57734 \\
\hline T value & & 2.62297 & 4.63994 \\
\hline P value & $* * *$ & $<0.05$ & $<0.05$ \\
\hline
\end{tabular}

Table : (4 ) showing the Quantitative results of measurements of the capsule thickness

*** Significant changes between metal fillers and control group at $\mathrm{P}<0.05$ 


\section{Discussion}

Acrylic resins are widely used materials for denture base processing because they are ease to manipulate . Addition of metals to the acrylic resin was tried by many investigators ; Silver and Aluminum were tried by Schajpal and Sood (1989) and Cupper was tried by Watah et al (2000). Metals improved the thermal conductivity as well as the mechanical properties of the resin. Similar results was found in this study with $2 \%$ concentrations of $\mathrm{Al}$ and $\mathrm{Ag}$ metals when mixed with the heat acrylic resin. Both the transverse and impact strengths were increased. The subcutaneous C.T. reaction was examined with acrylic resin implants containing $2 \% \quad \mathrm{Al}$ and $\mathrm{Ag}$ concentrations. The tissue reaction against metal free control implants was minimal in the form of thin C.T. capsule formed mainly of collagen fibers and fibroblasts. The mean thickness of the capsule was ( 40.4 43.7$)$ um. This tissue compatibility was attributed to the high purity and low level of residual monomer in the acrylic resin (Fahim et al ; 1971). However the tissue reaction with Aluminum was extensively expressed with the thick capsule and the marked cellularity . Histological results showed marked fibroblasts proliferation forming a C.T. capsule with mean thickness(190.6 \pm 3.9$)$ um. infiltrated with different inflammmatory cells extravas ated from the surrounding congested vessels. The mean cell number was $(650 \pm 0.69)$ cell /area. The same results have been reported by Kraft et al.(2000) and wataha et al.(2000). Althougth $\mathrm{Al}$ and $\mathrm{Ag}$ showed activation of the surrounding tissue against subcutaneous implants ; reduced cellular proliferation and activity were noticed with silver. The mean cell number was $(515 \pm 0.46)$ cell /area and the mean thickness of the capsule was
(122.1 \pm 16.6$)$ um . Similar results were reported by Kraft et al(2000) and Wataha et al.(2000).

Aluminium implants releases Aluminum element into the surrounding tissue ( Wang et al ;1992 ). This free element is phagocytosed by macrop hages ( Elson et al ;1993 ). Also ; this low dose of $\mathrm{Al}$ was reported to have mitoginic activity (Jeffery et al ;1994 ) and stimulates DNA synthesis (Quarles et al;1 994) Therefor Aluminum stimulates the fibroblast cell activity and division (Zaman et al ; 1992 ) forming the capsule and inducing the inflammatory reaction with marked cellular activity including macrophages; plasma cells; eosinophils and other leucocytes (Garacia et al ; 1995 ). The persisted tissue reaction after 4 weeks in the form of thick capsule might be related to the intermolecular cross links between the formed collagen fibrills as reported by Zhue et al ( 1990). However Rowatt et al (1979) reported that this tissue reaction was related to the binding action between Aluminum and the phosphorelated serins in tissues. Threfore the binding activity of the added metal to the tissue protein is an important factor in determining the tissue response. In conclusion the addi tion of low concentrations of $\mathrm{Al}$ and $\mathrm{Ag}$ to the acrylic resin improved the mechanical properties but the tissue reaction with $\mathrm{Ag}$ was better than with Al. Fibroblasts were the prominent cells in the tissue reaction. However these results are encouraging to think in Aluminum as Silver substitute especially for external reconstructive purposes .

\section{References}

1. A.D.A.: Americal Dental Associan (1982) : 1-Denture base polymers . J . A. D . A . $90: 451-458$ 
2. Delmont J.(1961): 2-Metal filled plastics New York; Reinhold pub . 15 18

3. Dixon D, L.; Eksrand $\mathbf{K}$.G. and Breeding L. C. (1991): 3-The transv erse strength of three denture base resins . J . Proth . Dent . 66: $510-513$

4. Elston D . M . ; Bergfield W . F . ; and Mcmahon J . T . (1993 ) : 4Aluminum tatto : a phenomenon that can resemble parasitized histiocytes . J . Cutan . Pathol . AUG . 20 ( 40 ) : 326

5. Fahim M. S. El sergany M. Naser M. and El khashab M. (1971) : Rat connective tissue response to acrylic resin cured at variable times Egypt. Dent. J. $17: 223$

6. Garacia P.V . ; Pujol R . M .; Alomar A . ; Cistero A . ; Curell R . ; Fernandez F . M . ; and Demoragas J .M . (1995) : ersistant subcutaneous nodules in patients hyposensitized with Aluminum containing allergen extracts . Arc . Dermatol . DEC . 131 (12) : $1421-4$

7. Habal M. B. and Powell R. D. (1980): 7-Biophysical evaluation of tissue response to implanted polymers. J. Bio Mat . Res . 14-446

8. Hodosh M . ; P ovar M . and Snklar G. (1970) : The dental polymer implant concept J . Proth . Dent . 22:371-380.

9. Jeffery E .H . ; Abren K .;Burgess E .; Cannata J. and Greger J . L . (1996) :Systemic Aluminum toxicity : effects . on bone, hematopoietic tissue, and kidney .J . Toxicol . Environ health . Aug . $30 ; 48$ (6) : 649 - 65

10. M.; Arens S.; Manger M. and vollonar B. (2000): Kraft C .N Hansis 10-Striated muscle microvascular response to Silver implants : A comparative In Vivo study with Titanium and stainless steel . J . Biomed . Master Res . FEB . 49 ( 2 ) : 129-9
11. Omar E and Shehata M . ( 1993 ) : ffect of metal fillers on the level of residual monomer of acrylic resin . Al azhar Dent . J . $5: 1-13$

12. Quarles L.D; Hartle J. E; Middleton J . P . ; zhang J . ; Arthur J . M and Raymond . J . R (1994) :Aluminum induced DNA Synthesis in osteoblasts : mediation by a $\mathrm{G}$ - protteun coupled cation sensing mechanism . J . Cell Biochem . Sep . ; 56 (1) : 106 - 17

13. Ragab A . Y . ( 1992 ) :Study of some physical and mechanical properties of metal filled acrylic resin. Master thesis in proth . Alex . Univ .

14. Rowatt E . ; Sorensen E . S . ; Triffit $\mathbf{J}$. ; Viess A . and Williams $\mathbf{R}$. J . (1997) : An examination of the binding of Aluminum to protein and mineral components of bone and teeth . J .Inorg . Biochem . DEC . 68 (4 ) : $235-8$

15. Sehajpal S. B. and Sood V. K. (1989): 15-Effect of metal fillers on some properties of acrylic resin . J . Proth . Dent . $61: 746-571$

16. Wang Z .X .; Chai B . F . ; Ye Y . Q . and Fang Q.Y.(1992): Local changes in Aluminum ; Calcium and Phosphorus content of bone caused by Aluminum implant Chin . Med . J . ( Eng ) Sep . 105 ( 9 ) : $749-52$

17. Wataha J . C . ; L ockwood P . E .and Schedle A.J. (2000): Effect of Silver ;Cupper ; Mercury ; and Nickel ions on cellular proliferation during low dose exposure . J . Biomed . Master . Res . NOV ; 52 ( 2 ) $360-4$

18. Zaman K . ; Mukhtar M . ; Siddique H . and Miszta H . (1992) :The effect of Aluminum on the stroma cells ( in vitro ) on bone marrow in rats . Toxicol . ind . Health . Jan . Apr . ; 8 (1-2) : $103-9$

19. Zhu J.M. ;Huffer w.;Alfrey A. C.(1990) :Effect of aluminum on bone matrix . Kidney Inter . 38 (6) :1141-5 
تقييم استجابة النسيج الضام تحت الجلا لعينات مغروسة من اكريل راتنجي مخلوط بحثوات معدنية

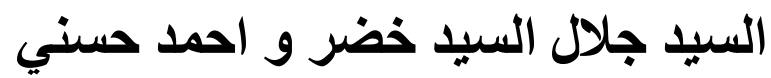
قسم الهستولوجيا بكلية الطب بالقاهرة وقسم التركيبات بكلية طب الأسنان جامعة الأزهر أنمر

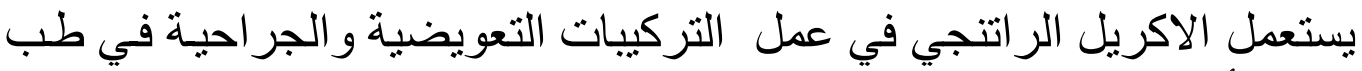

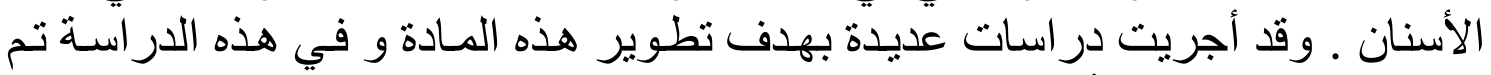

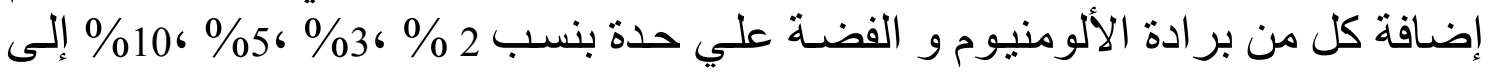

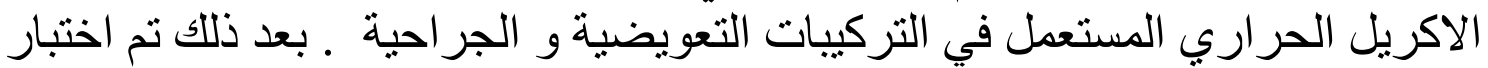

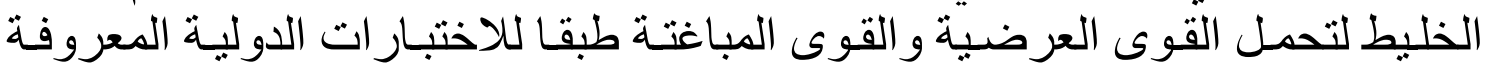

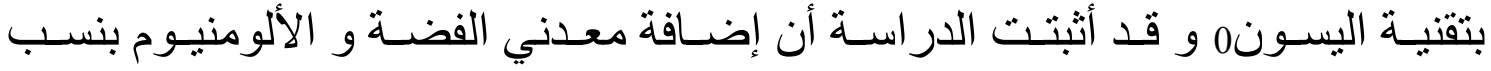

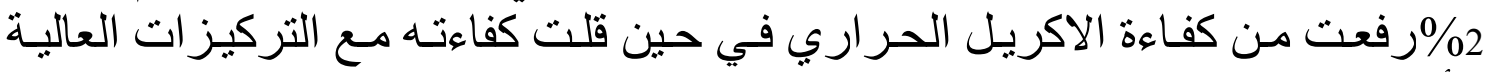

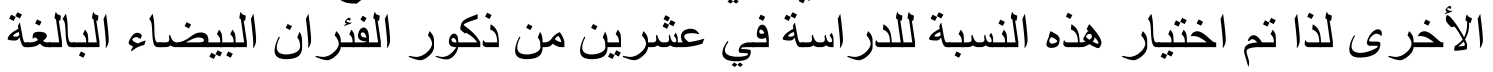

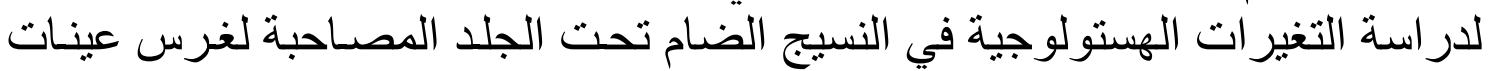

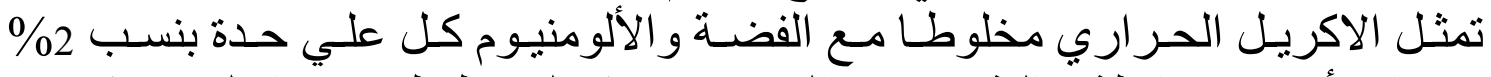

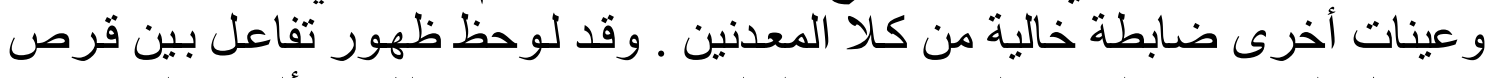

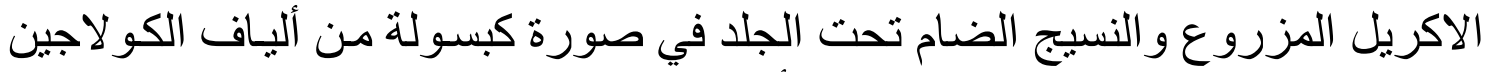

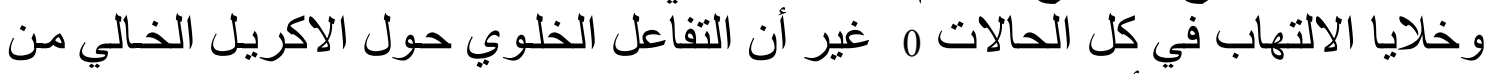

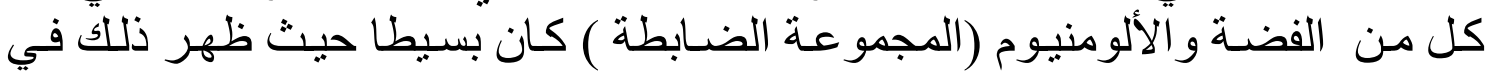

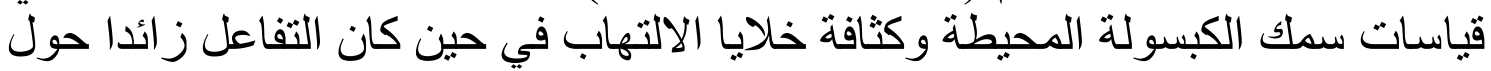

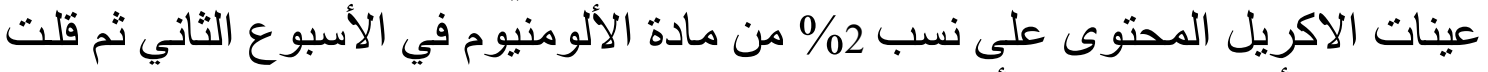

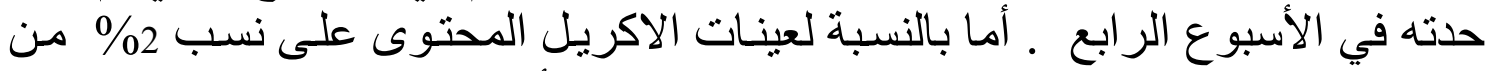

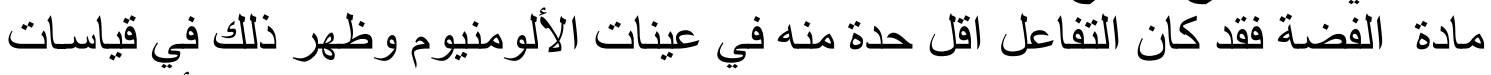

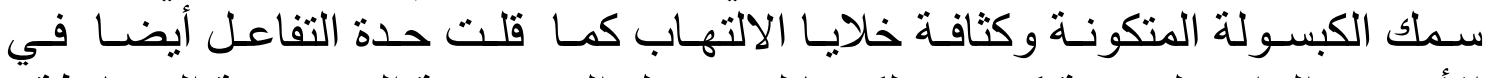

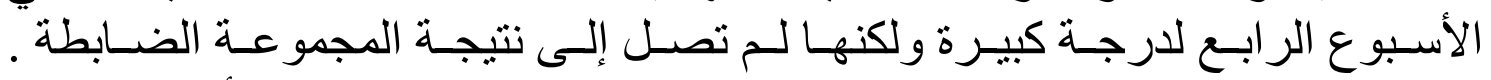

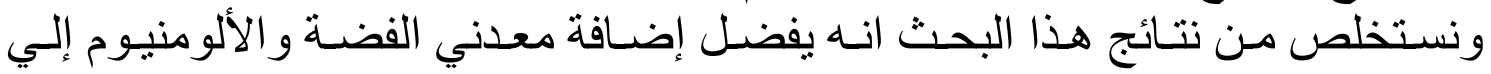

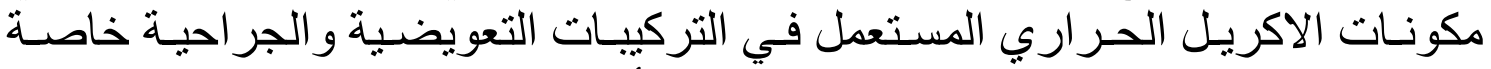

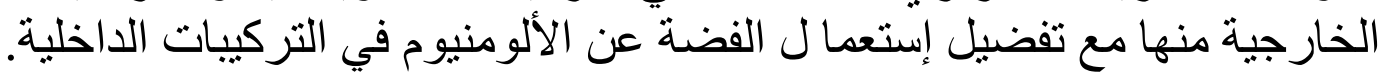

